\title{
SHARKS AND BATOIDS [SUBCLASS ELASMOBRANCHII) CAUGHT IN THE INDUSTRIAL FISHERIES OFF THE BRAZILIAN NORTH COAST
}

\author{
TUBARÕES E BATOIDES ISUBCLASSE ELASMOBRANCHIIJ CAPTURADOS NA PESCA INDUSTRIAL DA \\ COSTA NORTE BRASILEIRA
}

\section{TIBURONES Y BATOIDES (SUBCLASE ELASMOBRANCHII) CAPTURADOS EN LA PESQUUERÍA INDUSTRIAL FRENTE A LA COSTA NORTE DE BRASIL}

\author{
Alexandre Pires Marceniuk ${ }^{1,2}$ \\ Ronaldo Borges Barthem \\ Wolmar Benjamin Wosiacki \\ Alex Garcia Cavalleiro De Macedo Klautau² \\ Teodoro Vaske Junior ${ }^{3}$ \\ Matheus Marcos Rotundo \\ Ana Patricia Barros Cordeiro 5 \\ João Gomes Romão-Júnior ${ }^{6}$ \\ Wagner César Rosa dos Santos ${ }^{2,7}$ \\ Thayson da Silva Reis \\ Mairink Ribeiro Muniz ${ }^{7}$ \\ Gustavo Stabile Cardoso ${ }^{4}$ \\ Sarah TFL Viana ${ }^{9}$
}

\begin{abstract}
The Brazilian North coastline comprises a total area of approximately 223,000 $\mathrm{km} 2$, representing one of the world's most essential fishing grounds. Availability of data on the diversity of fishes caught in the industrial fishery trawlers in the region are
\end{abstract}

1 Museu Paraense Emílio Goeldi (MPEG), Programa de Capacitação Institucional, Av. Governador Magalhães Barata, 376, São Brás, 66040-17o Belém, PA, Brazil. (APM) a_marceniuk@hotmail.com, (RBB) ronaldo.barthem@hotmail.com, (WBW) wolmar@museu-goeldi.br.

2 Centro de Pesquisa e Gestão de Recursos Pesqueiros do Litoral Norte (CEPNOR), 66077-830, Belém, Pará, Brazil. (AGCMK) alex.klautau@icmbio.gov.br.

3 Universidade Estadual Paulista Júlio de Mesquita Filho (UNESP) , 11330-90o, São Vicente, SP, Brazil. (TVJ) teovaske@gmail.com.

4 Acervo Zoológico da Universidade Santa Cecília (AZUSC-UNISANTA), 11045-907, Santos, SP, Brazil. (MMR) mmrotundo@unisanta.br., (GSC) stabile.gustavo@unisanta.br.

5 Universidade da Amazonia (UNAMA), 66035-19o, Belém, Pará, Brazil. (APBC) anapaty2301@gmail. com.

6 Instituto Federal do Pará (IFPA), 3201-170o, Belém, Pará, Brazil. (JGRJ) romaojjr@gmail.com.

7 Universidade Federal Rural da Amazônia (UFRA), 66077-83o, Belém, Pará, Brazil, (WCRS) wagpesca@ yahoo.com.br., (MRM) mairinkmuniz@hotmail.com.

8 Universidade Federal do Pará (UFPA), 66077-83o, Belém, Pará, Brazil. (TSR) thayson.pesca@hotmail. com.

9 South African Institute for Aquatic Biodiversity, Private Bag 1015, Grahamstown, 6140, South Africa. (SV) stviana@gmail.com. 
usually limited to the commercially important and targeted species. Knowledge gaps on the related marine fish fauna are eminent, which hamper both fisheries and conservation efforts of the local biodiversity. A comprehensive taxonomic list of elasmobranch species captured off the North coast from Brazil through industrial trawl fishery is provided. Trawling operations acting regionally included pinkshrimp and several fish (outrigger trawling) and piramutaba catfish (pair trawlers). Sixty-eigth elasmobranch species belonging to 20 families and nine orders were recorded for this region, according to fish collection, fishery observer and literature data. Thirty-two are by-catch species caught in the local trawl operations, including endemic and rare species as well as four new records and one possible undescribed species of electric ray.

Keywords: elasmobranch; industrial fisheries; biodiversity; conservation; Brazilian North coast.

\section{Resumen}

La costa norte brasileña comprende un área total de aproximadamente $223.000 \mathrm{~km} 2$, que representa uno de los caladeros más esenciales del mundo. La disponibilidad de datos sobre la diversidad de peces capturados en los arrastreros de pesca industrial en la región generalmente se limita a las especies comercialmente importantes y seleccionadas. Las brechas de conocimiento sobre la fauna de peces marinos son eminentes, lo que dificulta tanto la pesca como los esfuerzos de conservación de la biodiversidad local. En este trabajo se proporciona una lista taxonómica integral de especies de elasmobranquios capturadas en la costa norte de Brasil a través de la pesca de arrastre industrial. Las operaciones de arrastre que actúan a nivel regional incluyeron camarones rosados y varios peces (arrastre de estabilizadores), asi como el bagre piramutaba (arrastreros de parejas). Se registraron 6o especies de elasmobranquios pertenecientes a 20 familias y nueve órdenes para esta región, de acuerdo con la recolección de peces, el observador de pesca y los datos de la literatura. Treinta y dos son especies de captura secundaria obtenidas en las operaciones locales de arrastre, incluidas especies endémicas y raras, así como cuatro nuevos registros y una posible especie de raya eléctrica no descrita.

Palabras llave: elasmobranch; pesca industrial; biodiversidade; conservación; Costa norte brasileña.

\section{Resumo}

A costa norte do Brasil compreende uma área total de aproximadamente $223.000 \mathrm{~km} 2$, representando uma das áreas de pesca mais importantes do mundo. A disponibilidade de dados sobre a diversidade de peixes capturados na pesca industrial de arrasto de fundo da região é limitada apenas às espécies comercialmente importantes. Esta lacuna de conhecimento da fauna de peixes marinhos é preocupante, por dificultar o monitoramento da pesca, assim como esforços de conservação da biodiversidade local. Uma lista taxonômica de Elasmobrânquios capturados na costa norte do Brasil pela pesca industrial de arrasto de fundo é aqui apresentada. As operações de arrasto que atuam sobre o camarão-rosa e peixes diversos (arrasto de portas) e a Piramutaba 
(parelhas) foram aqui monitoradas. Com base na observação de bordo, acervo de coleções zoológicas e literatura, 68 espécies de Elasmobrânquios, pertencentes a 20 famílias e nove ordens, foram registradas para a região. Trinta e duas espécies foram registradas como fauna acompanhante da pesca de arrasto, incluindo espécies endêmicas e raras, bem como quatro novos registros e uma possível espécie não descrita de raia-elétrica.

Palavras-chave: elasmobrânquios; pesca industrial; biodiversidade; conservação; costa norte do Brasil.

\section{INTRODUCTION}

Elasmobranch fishes (batoids and sharks) currently comprise 1,139 species worldwide in which 224 species occur in Brazil with distribution in marine, brackish and freshwater environments from shallow coastal waters to deep oceanic zones (Weigmann 2016). Elasmobranches are extensively caught as by-catch in industrial and artisanal fisheries as part of the global effort on targeting commercially important teleost species. Usually, sharks and batoids are captured using longlines, gill nets, purse and beach seine nets, and demersal trawls (Lessa et al. 1999). Shark meat exhibits reduced commercial values when compared to those of teleosts. Shark finning (and that also includes batoids), however, represents a valuable economical trend within the fishing industry in Brazil and elsewhere (Ussami 2015; Barreto et al. 2017). Reduction of fishing stocks and growing demand of protein for consumption has lately boosted the exploration of the elasmobranch fishing grounds that often are sold as mislabelled seafood products national and internationally (Bornatowski et al. 2017).

Annnually, 12,00o and 5,00o tons of sharks and batoids, respectively, are caught in the Brazilian fishing industry which place the country within the sixth highest sellers of shark meat worldwide (IUCN 2018; IBAMA/MMA 2007; Feitoza et al. 2018). Fisheries statistics from industrial and artisanal fisheries in Brazil and particularly at the North coast, where Pará State is the second in fishing production of the country, are lacking since 2017 (Pinheiro and Fredou 2004; Cintra et al. 2015; Lutz et al. 2016; Klautau et al. 2016), which hampers responsible conservation efforts. Furthermore, growing fishing interests in elasmobranch species of this region is alarming (Fredou and Asano-Filho 2006) as it functions as nursery area (SBEEL 2005).

The reliable identification of sharks and batoids species from the Brazilian North coast is a fundamental criteria for fisheries zoning as well as to the knowledge improvement on the diversity of the marine environment and the fish communities affected by fisheries activities in the region (sensu Manthey and Fridley, 2009). Inaccurate and unavailability of taxonomic data on sharks and batoids species captured through outrigger trawlers hamper the development of effective local 
conservation measures and management of the exploited ecosystems (Thrush et al., 1998; Greenstreet and Rogers, 2004; Juan and Demestres, 2012).

In this context, the present study intends to provide a comprehensive inventory of the elasmobranch species caught in the industrial fisheries off the North coast of Brazil at the pink-shrimp, several fish, and piramutaba catfish trawling operations. Regional elasmobranch diversity is also investigated herein through literature review in order to understand the status of the taxonomic knowledge.

\section{MATERIAL AND METHODS}

\section{Study area}

Brazilian North coastline comprises the region between Oiapoque (04023'N) and Parnaíba (02053'S) River mouths which discharge sediments in the Western Atlantic Ocean (Fig. 1). Usually, it is divided into three sectors (Studart-Gomes 1988): (i) Maranhão coast located between Parnaíba River mouth (02053'S) and Cape Gurupi (oo053'S) off Pará state which is characterized by muddy and sandy beaches, (ii) Pará coast (02030'N, 00050'S) with predominantly muddy bottoms, and (iii) Amapá coast $\left(04023^{\prime} \mathrm{N}, 02030^{\prime} \mathrm{N}\right)$ within Cape Orange with hard and rocky bottoms. This region is embedded within a vast shrimp fishing ground that extends northwestwards to an area adjacent to Orinoco River mouth in Venezuela (IBAMA 1997). The study area comprised the second and third sectors where industrial fisheries based in Belém, Pará state are intensively operating within the continental shelf (Figure 1) (Marceniuk et al. 2019). 


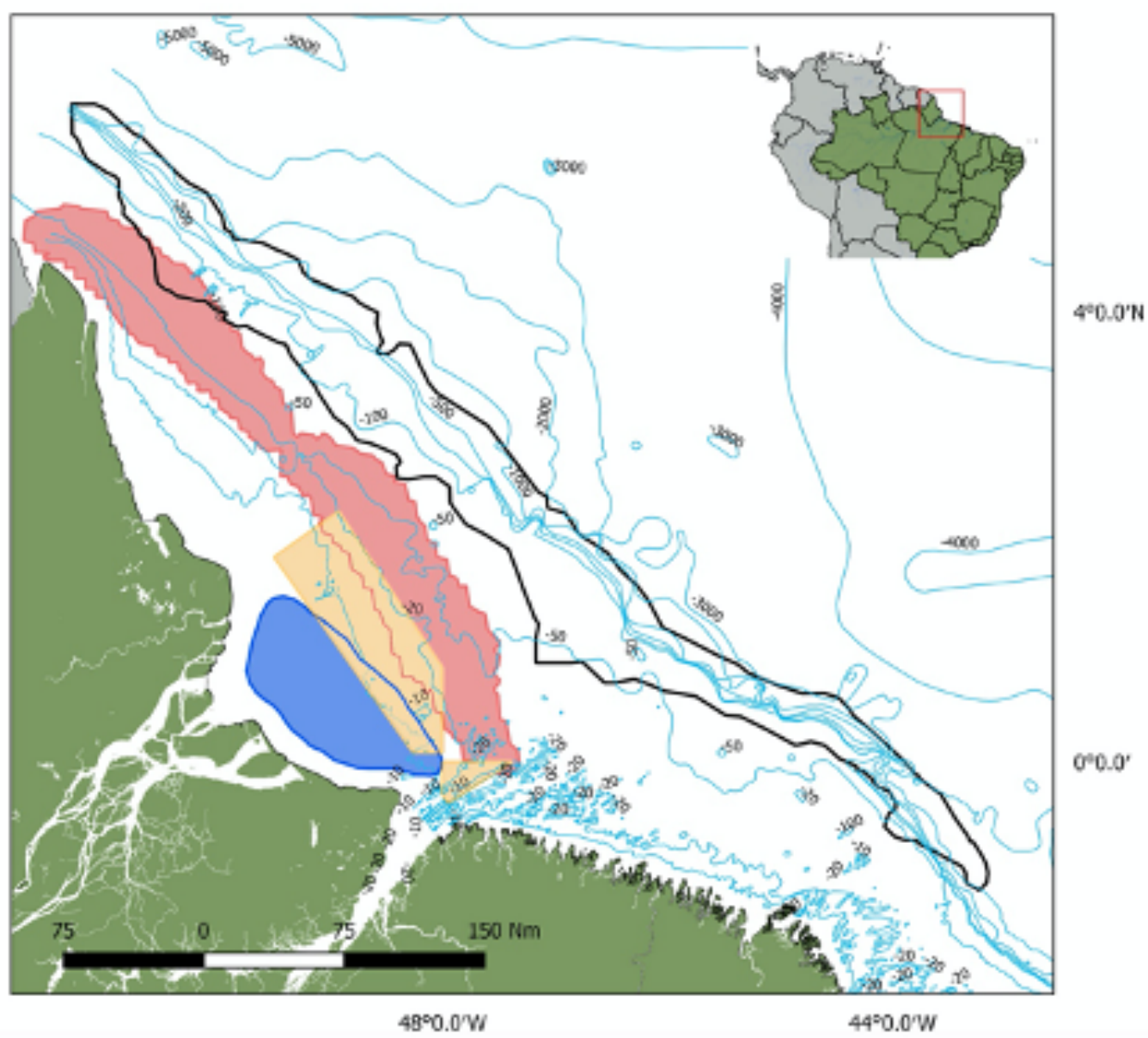

Figure 1. Industrial trawling zone off the North coast of Brazil (modified from Aragão et al., 20o1; Brasil, 2011). Outriggers that target pink-shrimp (red), several fish (orange) (outrigger trawling) and Piramutaba catfish (blue) (pair trawlers). The Great Amazon Reef System as defined in Moura et al. (2016) is in shaded black.

\section{Material examined}

Species-specific accounts were based on fishery observer data collected between 2016 and 2018 from the Centro Nacional de Pesquisa e Conservação da Biodiversidade Marinha da Costa Norte do Brasil (CEPNOR) in Belém, Pará state, Brazil. A total of 522 trawls were monitored during the study period, corresponding to 1.666 operational hours and 277 days at sea, including 164 days during the shrimping season and 103 during the off season (Fig. 2A). Photographs of specimens were taken onboard the fishing vessels. Examination of specimens collected in Amapá and Pará were also included in the analysis and data obtained from the following ichthyological collections: Museu Paraense Emílio Goeldi, Belém (MPEG); Zoological collection of the Universidade Santa Cecilia, Santos (AZUSC); Laboratório de Biologia e Genética de Peixes (LBP) from the Universidade Estadual Paulista Júlio de Mesquita, Botucatu. 
Additional data were obtained from the literature that cite, list or describe elasmobranch species off the Brazilian North coast: species available in the literature on bottom trawling (Pinheiro and Fredou 2004; Cintra et al. 2015; Klautau et al. 2016; Lutz et al. 2016; see Table $1 \mathrm{~B}$ ); species recorded in taxonomic works (Lessa et al. 1999; Almeida et al. 2008; see Table $\left.{ }_{1} C\right)$; species recorded in exploratory fishing work (Asano-Filho et al. 2005, 2007; Fredou and Asano-Filho 2006; Oliveira et al. 2007; see Table $1 \mathrm{D}$ ); and species recorded in molecular identification work (Carmona et al. 2008; Rodrigues-Filho et al. 2012; Palmeira et al. 2013; Gemaque 2017; Silveira 2017; Feitosa et al. 2018; see Table $1 \mathrm{E})$.

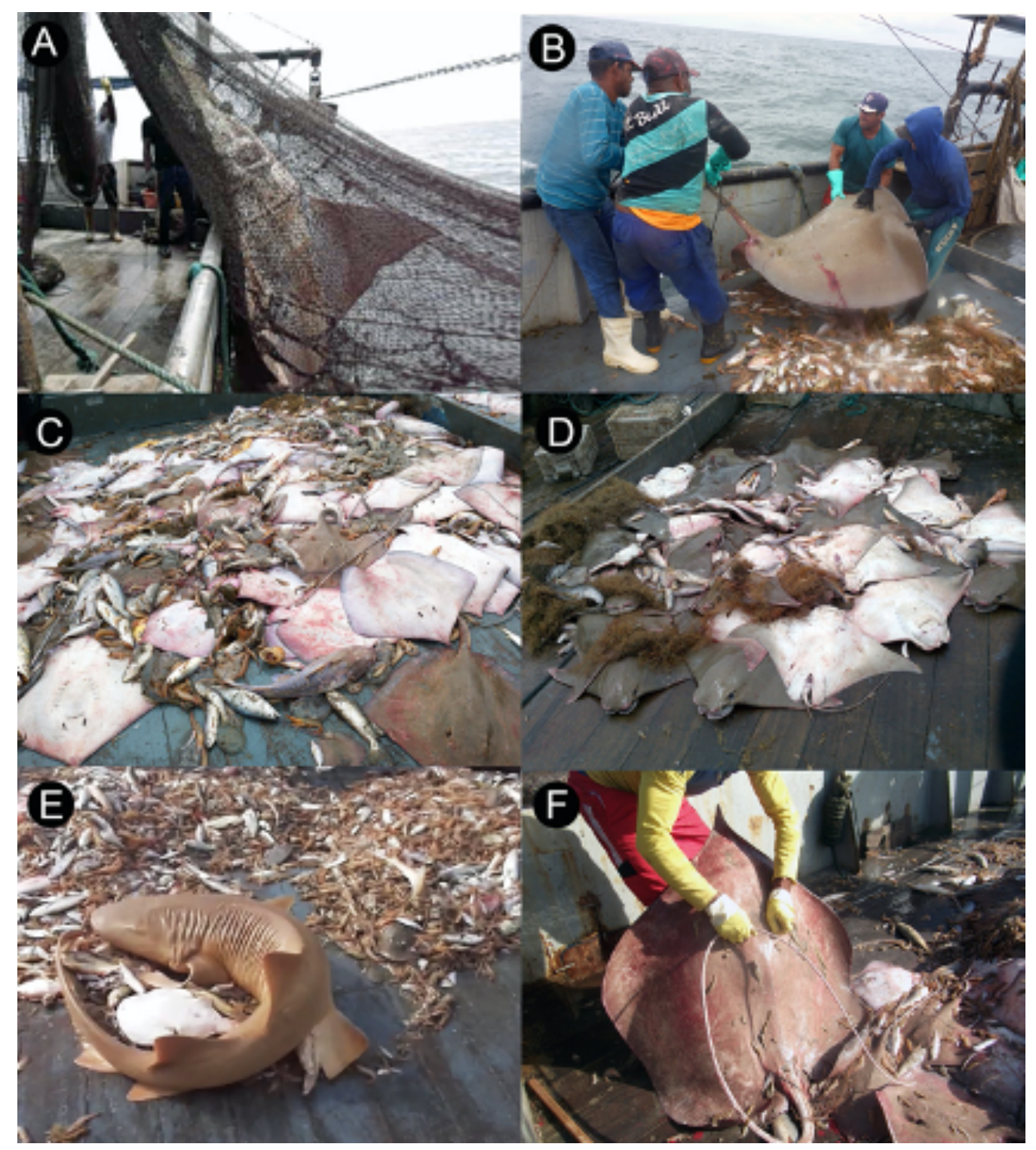

Figure 2. By-catch elasmobranches exploited off Brazilian North coast, showing fishing observers of the Centro de Pesquisa e Gestão de Recursos Pesqueiros do Litoral Norte (CEPNOR) onboard the fishing trawl vessels. A. Pristis pristis. B. Hypanus americanus. C. Hypanus guttatus. D. Rhinoptera bonasus. E. Ginglymostoma cirratum. F. Fontitrygon geijskesi. 


\section{Taxonomy and ecology}

Species identifications are based on Gomes et al. (2010), Ebert et al. (2013), FAO (2016) and Last et al. (2016a,b,c) besides comparative material and/or consultation with experts. Classification and updated nomenclature of species follow, respectively, Van der Laan et al. (2019) and Fricke et al. (2019). Genera and species-names for each family are given in alphabetical order. Species were also classified according to distribution area (Table ${ }_{1} \mathrm{~F}$ ) and ecological habits, following Froese and Pauly (2019) and Marceniuk et al. (2019) (Table $1 G$ ).

\section{Threatened status and fishing gear type}

Conservation status were also provided according to the International Union for Conservation of Nature (IUCN) Red List of Threatened Species (IUCN 2018) and/ or Livro Vermelho da Fauna Brasileira Ameaçada de Extinção (ICMBio/MMA 2018) (Table $1 \mathrm{H})$. Fishing gears that were applied for capturing each species off the North coast from Brazil are also listed (Table 1I).

\section{Taxonomic procedures}

The species labelled as "sp." represent a possible undescribed species currently under investigation by our research team: Narcine sp. (Rotundo et al. in preparation).

\section{RESULTS AND DISCUSSION}

\section{Elasmobranch diversity from the Brazilian North coast}

Based on the photographs and the specimens examined, a total of 34 species were caught in the trawl fisheries off the North Coast of Brazil between 2016 and 2018 (Tab. 1, Table $1 \mathrm{~A}$ ). Out of these only seven species were previously registered in studies about the fish fauna caught through the fishing trawls (see Pinheiro and Fredou, 2004; Cintra et al. 2015; Klautau et al., 2016; Lutz, et al. 2016, see Table 1B). Two species that were not observed during the present study were listed in these accounts (Table $1 \mathrm{~B}$ ). Three ray species are reported herein for the first time in the region: N. bancroftii; P. horkelii; $U$. jamaicensis; Narcine sp. (see Table ${ }_{1} \mathrm{C}-\mathrm{E}$ ). The latter species represents an undescribed species and it is under investigation by MM Rotundo and colaborators.

Forty-eight elasmobranch species are currently recognized in the study area (see Lessa et al. 1999; Santos et al. 2004; Almeida et al. 2008; Table 1C). Twenty-three species 
were also identified through the DNA barcoding of the (CO1) cytochrome oxidase-1 mitochondrial gene (Carmona et al. 2008; Rodrigues-Filho et al. 2012; Palmeira et al. 2013; Silva,2016; Gemaque 2017; Silveira 2017; Feitosa et al. 2018; Table 1E). Additionally, 27 species were previously listed in exploratory fisheries studies (e.g. Asano-Filho et al. 2005, 2007; Fredou and Asano-Filho 2006; Oliveira et al. 2007; TableiD). For the current data analysis, the diversity of sharks and batoids off the Brazilian North coast is represented by 69 species (Table 1). The complete data set (present study plus previously published data) supports that elasmobranches from the Brazilian North coast are classified within 20 families and nine orders of the Class Chondrichthyes (Tabela 1). Carcharhinidae (16 spp.) and Sphyrnidae (5 spp.) from the order Carcharhiniformes show the highest diversity followed by Potamotrygonidae (8 spp.), Dasyatidae (6 spp.) and Myliobatidae ( 5 spp.) from the order Myliobatiformes.

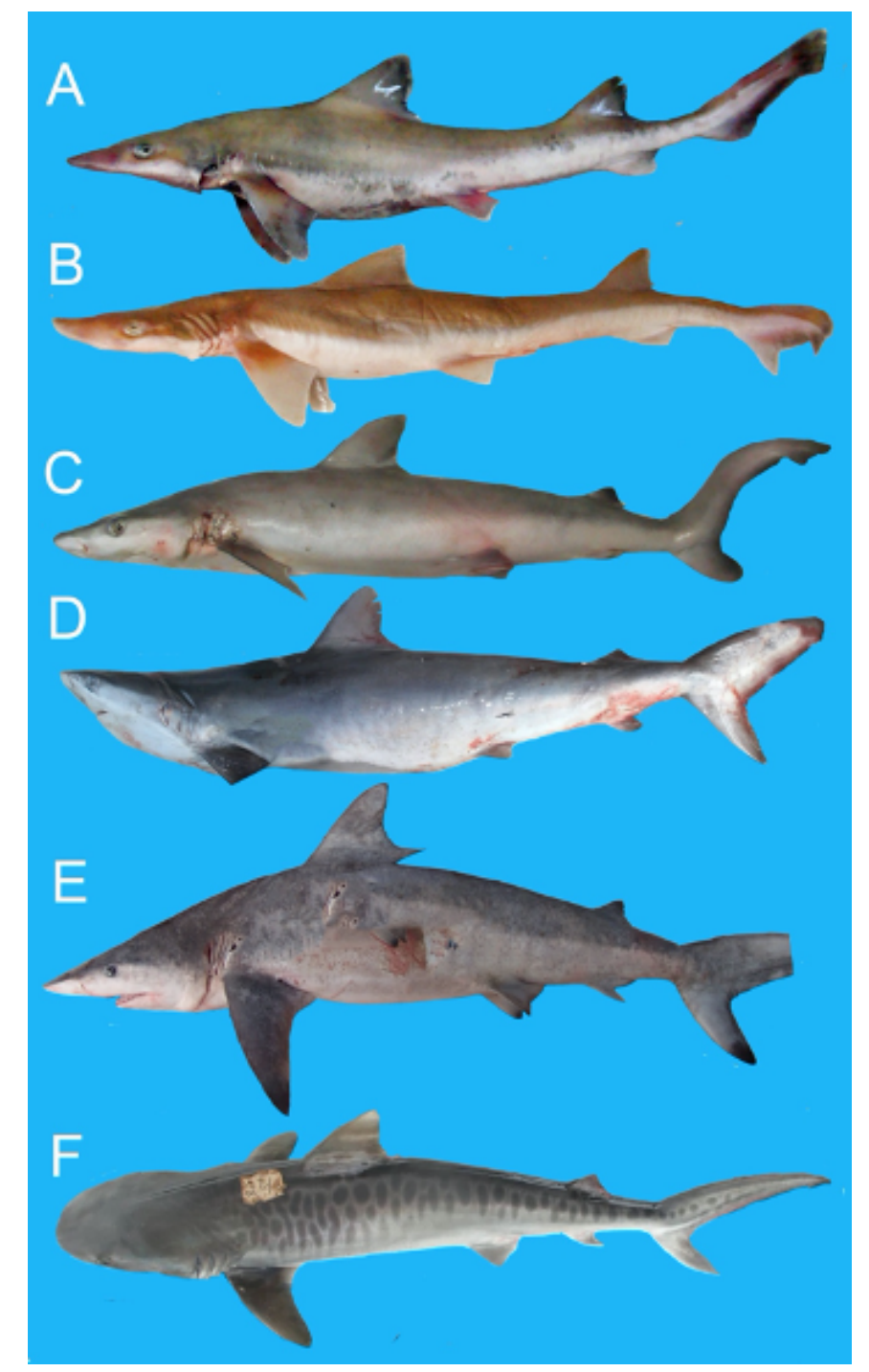

Figure 3. Species of sharks occurring in Belém, Pará state (order Carcharhiniformes): (A) Mustelus canis, MPEG 35158, 380 mm TL, (B) M. higmani, AZUSC 5016, 497 mm TL; (C) Carcharhinus acronotus, AZUSC 5655, $493 \mathrm{~mm}$ TL, (D) C. falciformis, not cataloged, (E) C. limbatus, not cataloged, (F) Galeocerdo cuvier, not cataloged. 


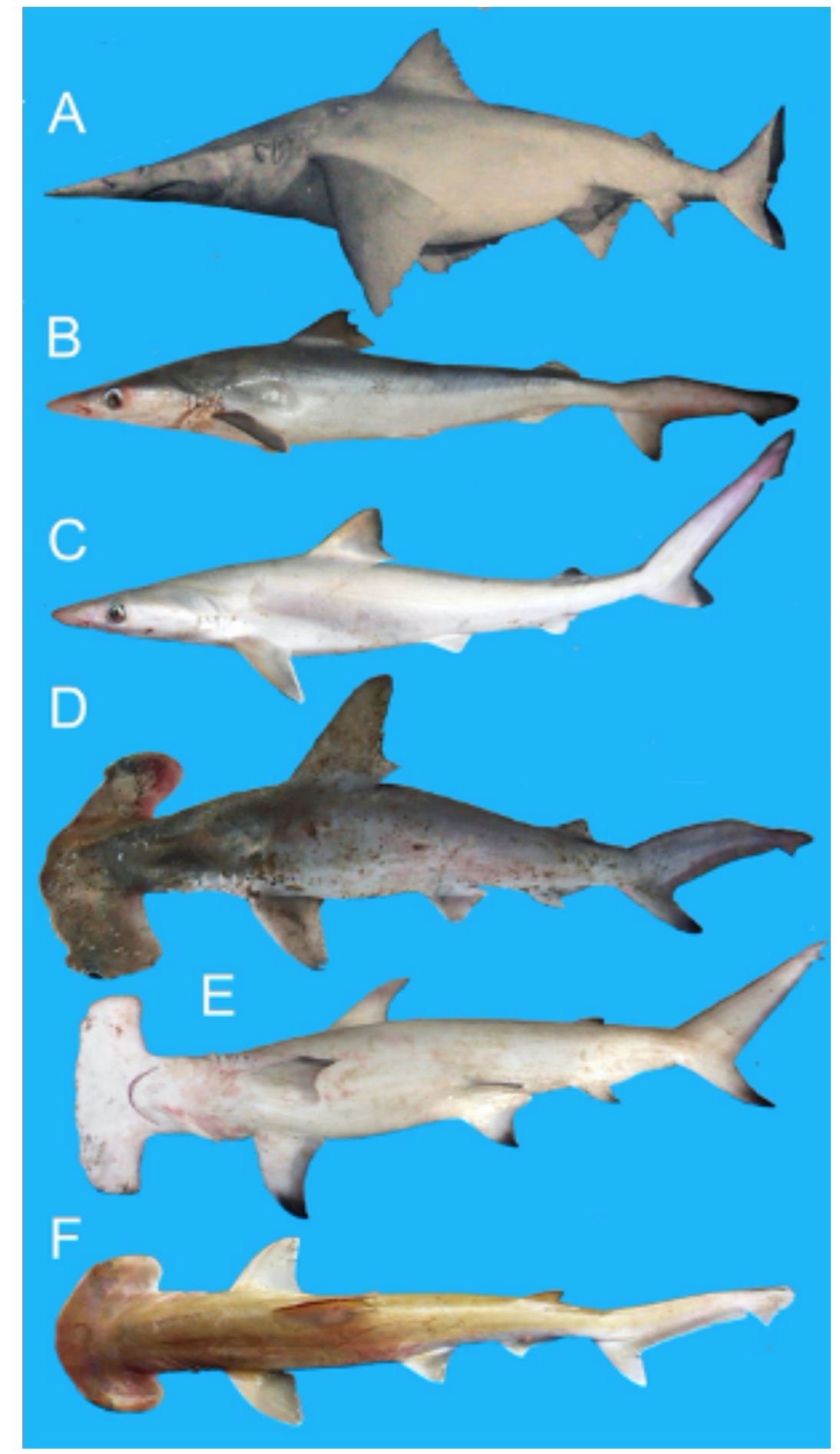

Figure 4. Species of the order Carcharhiniformes, family Carcharhinidae, (A) Isogomphodon oxyrhynchus, MPEG 1297, 360 mm TL; (B) Rhizoprionodon lalandii, AZUSC 5380, 401mm TL; (C) R. porosus, AZUSC 5395, 441 mm TL; (D) Sphyrna lewini, AZUSC 5565, 503 mm TL; (E) Sphyrna mokarran, not cataloged; (F) Sphyrna tiburo, AZUSC 5393, $447 \mathrm{~mm}$ TL. 
Twenty species (29.0\% of the total species listed here) have wide geographical distribution, 30 species (43.5\%) are broadly distributed along the Atlantic Ocean, whereas 11 species (15.9\%) are endemic to the Amazon-Orinoco Plume and also confined to a specific locality that where has been intensively exploited in trawling operations (Table $1 \mathrm{~F}$ ). The majority of the sharks and batoids caught in the region display coastal shallow waters and oceanic habits (49 and 13 species, respectively) while seven freshwater species (Potamotrygon and Plesiotrygon) are occasionally caught. These results thus support a much higher local diversity than previously thought for the Brazilian North region. However, local species richness is lower than other regions in the country such as for the Northeastern and Southeast Brazil in Gadig et al. (2000) and Gomes et al. (2010).

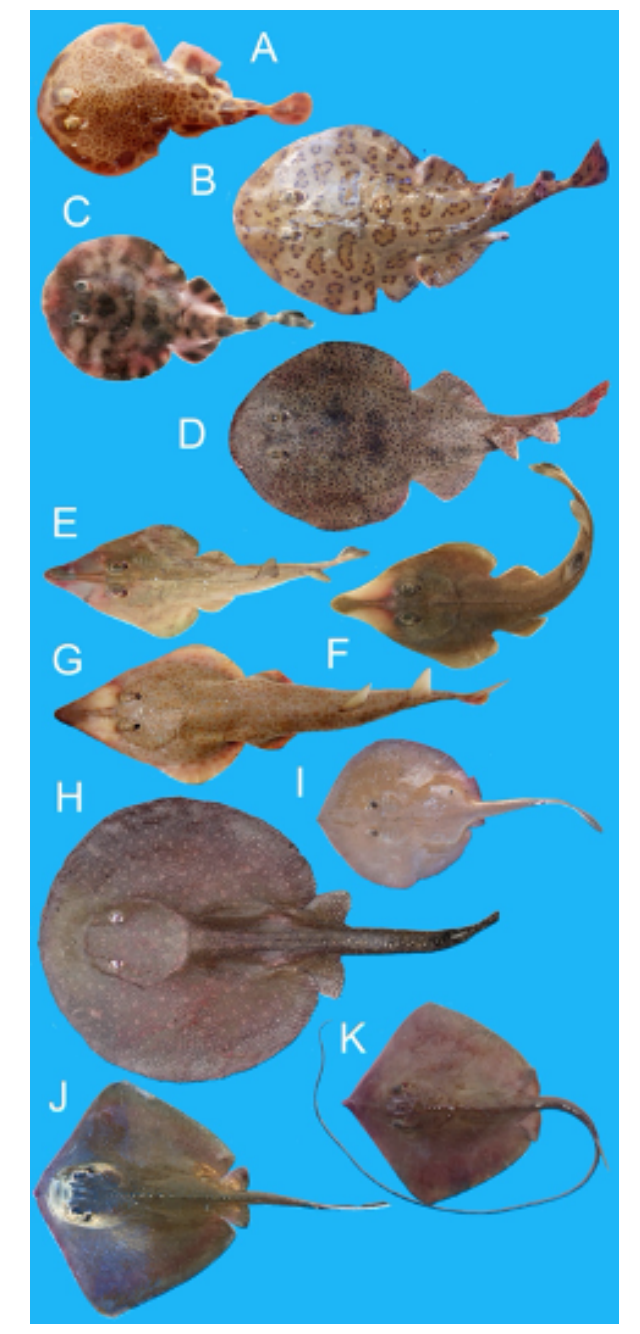

Figure 5. Batoid species caught off Belém, Pará state of the order Torpediniformes (A-D), Rhinopristiformes (E-G) and Myliobatiformes (H-K): (A) Diplobatis picta, AZUSC 5003, 75 mm TL; (B) Narcine bancroftii, MPEG 35118, 319 mm TL; (C) N. brasiliensis, AZUSC 5543, 86 mm TL; (D) Narcine sp., AZUSC 5406, 340 mm TL; (E-F) Pseudobatos horkelii, AZUSC 5356, 139 mm TL; (G) P. percellens, AZUSC 5373, 259 mm TL; (H) Urobatis jamaicensis, not cataloged; (I) Urotrygon microphthalmum, AZUSC 4985, 318 mm TL; (J) Hypanus americanus, AZUSC 4644, 795 mm TL; (K) H. guttatus, AZUSC 5300, 647 mm TL. 


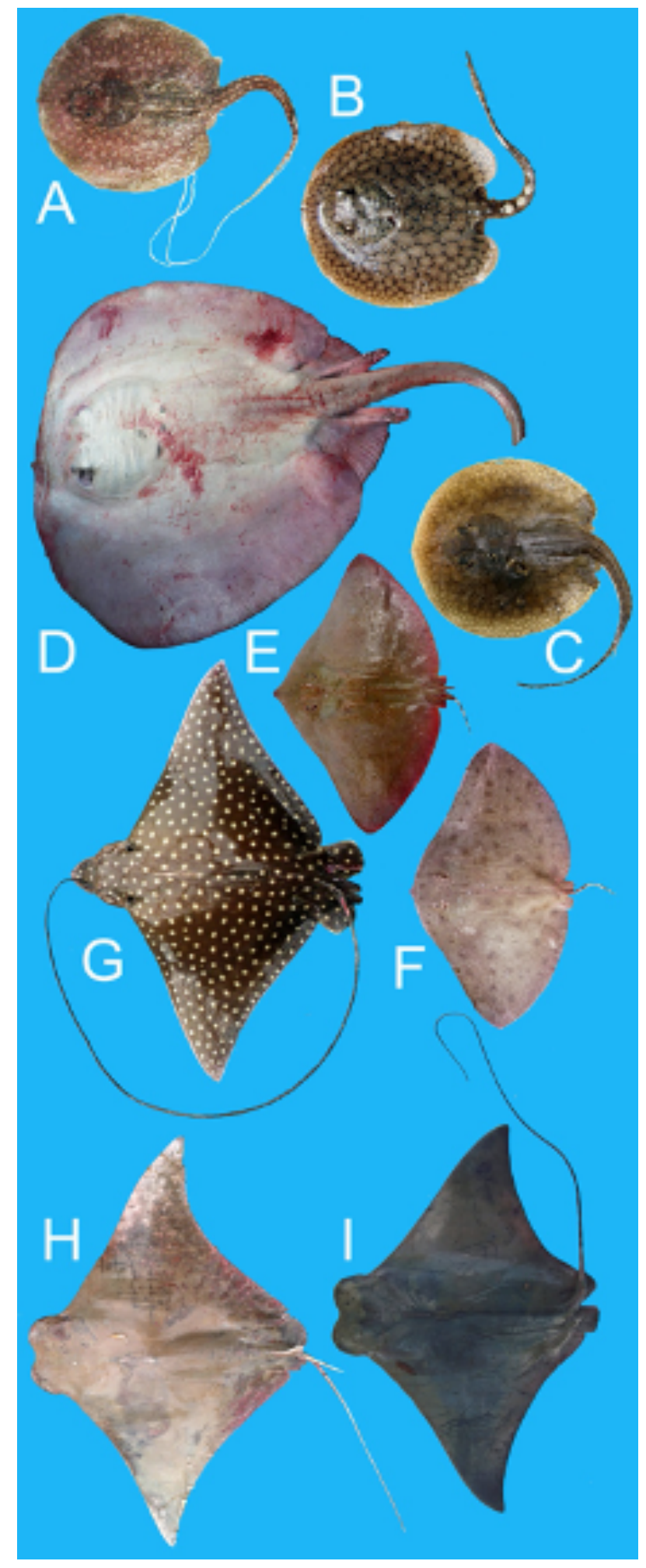

Figure 6. Other batoid species caught in the industrial trawl fisheries in the region (order Myliobatiformes): (A) Plesiotrygon iwamae, MPEG 35522, 500 SL, (B) Potamotrygon humerosa, MPEG 35526, 623 mm TL; (C) P. orbignyi, AZUSC 5002, $382 \mathrm{~mm}$ TL; (D) Styracura schmardae, not cataloged; (E-F) Gymnura micrura, AZUSC 4640, 167 mm TL; (G) Aetobatus narinari, not cataloged; (H) Rhinoptera brasiliensis, not cataloged; (I) R. bonasus, not cataloged. 


\section{Shark fishing exploitation in the region}

The most common fishing gear employed in the region is demersal trawls (39 species) followed by gill nets (for 28 species) and longlines (19 species) (Table 1 I). Out of the 69 species occurring along the Brazilian North coast, 36 elasmobranch species are associated to industrial trawl fisheries (Table $1 \mathrm{~A}-\mathrm{B}$ ). From these, nine species were previously reported in studies about fishery data using demersal trawls (e.g. Pinheiro and Fredou 2004; Cintra et al. 2015; Klautau et al. 2016; Lutz et al. 2016) (Table 1A,B) while only two species listed in these studies were not observed here (Table 1A,B).

\section{Local shark conservation}

Twenty-eight species $(39.7 \%$ of the total caught) are currently under threat according to the Red List of Threatened Species of the International Union for Conservation of Nature (IUCN 2018) and at "Livro Vermelho da Fauna Brasileira Ameaçada de Extinção" (Table $1 \mathrm{H}$ ): 13 species as critically endangered (CR); four as Endangered (EN); 11 as Vulnerable (VU). Conservation efforts are of major concern off the North coast of Brazil as many sharks and batoids are naturally vulnerable to overfishing due to their K-selected features which include slow growth, late maturity, long gestation period and low fecundity (Dulvy et al. 2014). Little information on species life cycles, population trends and threats are available, especially for local endemics (Lessa et al. 2000, 2016) as twenty-six elasmobranch species are classified as Data Deficient (DD) at the present.

\section{CONCLUSION}

Bottom trawl fisheries off the Northern coast of Brazil have targeted 34 elasmobranch species out of the 69 species occurring in the region, according to the fishery reports from between 2016 and 2018 together with data taken from fish collections and previously published studies. Eleven species (15.9\% of the total) are coastal and freshwater endemics from the Orinoco-Amazon plume. Industrial fisheries represent a significant economic activity in the region (IBAMA 2007). However, little is known about the fish diversity that are exploited (Marceniuk et al. 2019). Approximatelly, 65\%-90\% of the species listed here are locally exploited as by-catch. Yet, conservation efforts in the region are still neglected with exception to the Largetooth Sawfish Pristis pristis and the Smalltooth Sawfish P. pectinata as well as more six shark species and seven batoid species that are internationally protected by law through the Convention on International Trade in Endangered Species of Wild Fauna and Flora (CITES). Hence, this goes against the recommendations of the Brazilian Shark Conservation Planning (SBEEL 2005) that take into account 
conservation measures for protecting national species such as banning exploitation of certain species ("quati" Isogomphodon oxyrhynchus, and "rudela" Sphyrna lewini), creation of environmentally protected areas, environmental law enforcement and undertake effective fisheries observer and landing data.

Biodiversity knowledge is imperative for conservation and management of the natural aquatic resources worldwide. Species identification, for instance, guarantees reliable fishery data of commercially important species that are captured in direct or indirect fisheries (Bester-van der Merwe and Gledhill, 2015). Fisheries monitoring together with biological scientific surveys contribute to sampling of aquatic communities that are still poorly-known to science (Marceniuk et al. 2019) such as elasmobranches. Understanding the local fish fauna also supports studies that reveal regional environmental conditions and assists the fisheries zoning for creating novel fishing grounds. The latter usually contemplate the local diversity in terms of species richness, habitats and communities that are affected (sensu Manthey and Fridley 2009).

Inexistence of fisheries statistics in Brazil and, more specifically, in the Northern region disrupts effective monitoring of these natural resources and thus hampers future economical reliablity of this activity as species-specific reported catches data remains unknown. Beyond the political framework this scenario represents, the taxonomic impediment behind any existing Brazilian fishery data is characterized by the absence of species-specific identification and usage of vernacular names (e.g. cação, raia, tubarão). This is usually associated to minor investments in taxonomic research, ex-situ conservation actions (e.g. ichthyological collections) and lack of fish experts in the region as noticed in Marceniuk et al. (2013). For instance, Fontitrygon colarensis occurring exclusively in Pará State has not been collected since its original description in Santos et al. (2004) as it is observed in the present study and in recent molecular analysis of local species (e.g. Carmona et al. 2008; Rodrigues-Filho et al. 2012; Palmeira et al. 2013; Gemaque 2017; Silveira 2017; Feitosa et al. 2018; Table $1 \mathrm{E}$ ). It is thus not surprising that the known local elasmobranch diversity is significantly lower than neighboring areas from the Atlantic Ocean (see Weigmann 2016). Collecting efforts and research initiatives like the present one are urgently required in order to improve the biodiversity knowledge and catch data of sharks and batoids in the Brazilian Northen region.

\section{REFERENCES}

Almeida MP, Barthem RB, Viana A da S, Almeida PC. 2008. Diversidade de raias de água doce (Chondrichthyes: Potamotrygonidae) no estuário Amazônico. Arquivos de Ciências do Mar, 41:90-94. 
Aragão JAN, Cintra IHA, Silva KCA, Vieira IJA. 2001. A exploração camaroeira na costa Norte do Brasil. Boletim Técnico Científico do CEPNOR, 1:11-44.

Asano-Filho M, Holanda FCAF, Santos FJS, Cavalcante-Jr. TS. 2005. Recursos pesqueiros de grandes profundidades na costa norte do Brasil. Ministério do Meio Ambiente, Brasília. 8op.

Asano-Filho M, Santos FJS, Holanda FCAF. 2007. Composição da Fauna nas Pescarias Realizadas com Espinhel Pelágico na Costa Norte do Brasil Durante a Execução do Projeto Protuna. Arquivos de Ciências do Mar, 40:58-64.

Barreto RR, Bornatowski H, Motta FS, Santander-Neto J, Vianna GMS, Lessa R. 2017. Rethinking use and trade of pelagic sharks from Brazil. Marine Policy, 85:114-122. https://doi.org/10.1016/j.marpol.2017.08.016.

Bester-van der Merwe AE, Gledhill KS. 2015. Molecular species identification and population genetics of Chondrichthyans in South Africa: current challenges, priorities and progress. African Zoology: 1-13.

Bornatowski H, Braga RR, Barreto RP. 2017. Elasmobranchs consumption in Brazil: impacts and consequences. In: Rossi-Santos MR, Finkl CW (eds.) Advances in Marine Vertebrate Research in Latin America. Cham: Springer International Publishing, p. 251-262.

Carmona N, Sampaio I, Santos S, Souza RFC, Schneider H. 20o8. Identificação de Arraias Marinhas Comerciais da Costa Norte Brasileira com Base em Sequências de DNA Mitocondrial. Boletim Técnico-Científico do Cepnor, 8:51-58.

Cintra IHA, Klautau AGCM, Paiva KS, Silva KCA. 2015. Da captura incidental de Manta birostris (Chondrichthyes, Mobulidae) em pescaria de camarão-rosa na plataforma continental amazônica. Revista CEPSUL: Biodiversidade e Conservação Marinha, $4: 1-4$.

Dulvy NK, Pardo SA, Simpfendorfer CA, Carlson JK. 2014. Diagnosing the dangerous demography of manta rays using life history theory. PeerJ 2: e4oo.

Ebert DA, Fowler SL, Compagno LJV. 2013. Sharks of the world: a fully illustrated guide. London: Wild Nature Press, 528p.

Food and Agriculture Organization of the United Nations (FAO). 2016. Identification guide to common sharks and rays of the Caribbean, by Ramón Bonfil. FishFinder Programme. Rome, Italy. 
Feitosa LM, Martins APB, Giarrizzo T, Macedo W, Monteiro IL, Gemaque R, Nunes JLS, Gomes F, Schneider H, Sampaio I, Souza R, Sales JB, Rodrigues-Filho LF, Tchaicka L, Carvalho-Costa LF. 2018. DNA-based identification reveals illegal trade of threatened shark species in a global elasmobranch conservation hotspot. Scientific Reports, 8(1):3347.

Frédou FL, Asano-Filho M. 20o6. Recursos pesqueiros da região norte. In: Programa REVIZEE: Avaliação do Potencial Sustentável de Recursos Vivos na Zona Econômica Exclusiva: Relatório Executivo/MMA, Ministério do Meio Ambiente, Brasília, Brazil, pp. 121-152.

Froese R, Pauly D (Eds). 2019. FishBase. Available at www.fishbase.org. Accessed on o1 July 2019.

Fricke R, Eschmeyer WN, van der Laan R (Eds). 2019. Eschmeyer's Catalog of Fishes: Genera, Species, References. Available at http://researcharchive.calacademy.org/ research/ichthyology/catalog/fishcatmain.asp. Accessed on o1 July 2019.

Gadig OBF, Bezerra MA, Feitosa RD, Furtado-Neto MAA. 20oo. Ictiofauna marinha do Estado do Ceará, Brasil: Elasmobranchii. Arquivos de Ciências do Mar, 33(1-2):127-132.

Gemaque R, Monteiro ILP, Gomes F, Sodré D, Sampaio I, Sales JBL, Rodrigues Filho LFS. 2017. Why implement measures to conserve the diversity of Elasmobranchs? The case of the northern coast of Brazil. Revista da Biologia 17(2):1-7. https://doi. org/10.7594/revbio.17.02.01

Gomes UL, Signori CN, Gadig OBF, Santos HRS. 2010. Guia para a identificação de tubarões e raias do Rio de Janeiro. Rio de Janeiro: Technical Books. 234p.

International Union for Conservation of Nature (IUCN). 2018. TheIUCN red list of threatened species. Available at http://www.iucnredlist.org.

Instituto Brasileiro do Meio Ambiente e dos Recursos Naturais Renováveis (IBAMA). 1997. Camarão norte e piramutaba: Relatórios das reuniões dos grupos permanentes de estudos. Brasília: IBAMA; (Coleção Meio Ambiente; Série Estudos Pesca; 9).

IBAMA/MMA. 2007. Estatística da pesca 2005 Brasil. Grandes regiões e unidades da federação. Brasília, 108p.

ICMBio/MMA. 2018. Livro Vermelho da Fauna Brasileira Ameaçada de Extinção. Volume VI - Peixes. Brasília, DF, 1232p. 
Klautau AGCM, Cordeiro APB, Cintra IHA, Silva LEO, Bastos CEMC, Carvalho HRL, Ito LS. 2016. Analysis of the Industrial Fishing of Piramutaba Catfish, Brachyplatystoma vaillantii (Valenciennes 1840) in two Estuarine Areas of the Brazilian Amazon. PanAmerican Journal of Aquatic Sciences, 11:143-150.

Last PR, Naylor GJP, Manjaji-Matsumoto M. 2016a. A revised classification of the family Dasyatidae (Chondrychthyes: Myliobatiformes) based on new morphological and molecular insights. Zootaxa, 4139:345-368.

Last PR, White WT, Carvalho MR, Séret B, Stehmann MFW, Naylor GJP (Eds). 2016b. Rays of the World. Melbourne: CSIRO Publishing, 1577 p.

Last PR, Séret B, Naylor GJP. 2016c. A new species of guitarfish, Rhinobatos borneensis sp. nov. with a redefinition of the family-level classification in the order Rhinopristiformes (Chondrichthyes: Batoidea). Zootaxa, 4117(4):451-475.

Lessa R, Batista VS, Santana FM. 2016. Close to extinction? The collapse of the endemic Daggernose Shark (Isogomphodon oxyrhynchus) off Brazil. Global Ecology and Conservation, 7:70-81.

Lessa R, Santana FM, Batista V, Almeida Z. 2000. Age and growth of the Daggernose Shark, Isogomphodon oxyrhynchus, from northern Brazil. Marine and Freshwater Research, 51:339-347.

Lessa R, Santana FM, Rincon G, Gadig OBF, El-Deir ACA. 1999. Biodiversidade de Elasmobrânquios no Brasil. Ministério do Meio Ambiente, Programa Nacional da Diversidade Biológica (PRONABIO), Necton - Elasmobrânquios: Recife, 154 p.

Lutz Í, Lima WMG, Goncalves-Filho IA, Cintra IHA, Bentes B. 2016. Produção pesqueira desembarcada em um estuário do norte do Brasil (Bragança, Pará). Actapesca, 4:125136.

Manthey M, Fridley JD. 2009. Beta diversity metrics and the estimation of niche width via species co-occurrence data: reply to Zeleny. Journal of Ecology, 97:18-22.

Marceniuk AP, Caires R, Wosiacki WB, Di Dario, F. 2013. Conhecimento e conservação dos peixes marinhos e estuarinos (Chondrichthyes e Teleostei) da Costa Norte do Brasil. Biota Neotropica 13:251-259. 
Marceniuk AP, Rotundo MM, Caires R, Cordeiro APB, Wosiacki WB, Oliveira C, Serra RRMS, Romão-Júnior JG, dos Santos WCR, Reis TS, Muniz MR, Cardoso GS, Ferrari S, Klautau AGCM, Montag L. 2019. The bony fishes (Teleostei) caught by industrial trawlers off the Brazilian North coast, with insights into its conservation. Neotropical Ichthyology, 17:e180038[28].

Moura RL, Amado-Filho GM, Moraes FC, Brasileiro PS, Salomon PS, Mahiques MM, Bastos AC, Almeida MG, Silva JMJr, Araujo BF, Brito FP, Rangel TP, Oliveira BCV, Bahia RG, Paranhos RP, Dias RJS, Siegle E, Figueiredo AG, Pereira RC, Leal CV, Hajdu E, Asp NE, Gregoracci GB, Neumann-Leitão S, Yager PL, Francini-Filho RB, Fróes A, Campeão M, Silva BS, Moreira APB, Oliveira L, Soares AC, Araujo L, Oliveira NL, Teixeira JB, Valle RAB, Thompson CC, Rezende CE, Thompson FL. 2016. An extensive reef system at the Amazon River mouth. Science Advances, 2:e1501252.

Oliveira, G. M., Barros, A. C., Evangelista, J. E. V., dos Santos, A. R. B., Haimovici, M., Luciano Gomes Fischer, L. G. (2007). Prospecções na Região Norte. In: A prospecção pesqueira e abundância de estoques marinhos no Brasil nas décadas de 1960 a 1990: Levantamento de dados e Avaliação Crítica. Brasília: MMA/SMCQA, 330 p.

Palmeira CAM, Rodrigues-Filho LSF, Sales JBL, VallinotoM, Schneider H, Sampaio I. 2013. Commercialization of a critically endangered species (largetooth sawfish, Pristis perotteti) in fish markets of northern Brazil: authenticity by DNA analysis. Food Control 34:249-252.

Pinheiro LA, Frédou FL. 2004. Caracterização geral da pesca industrial desembarcada no estado do Pará. Revista virtual de Iniciação Científica da Universidade Federal do Pará. 2004; Available at http://www.cultura.ufpa.br/rcientifica/ed_anteriores/pdf/ ed_04_lap.pdf.

Rodrigues-Filho LF, Pinhal D, Sodré D, Vallinoto M. 2012. Shark DNAforensics: Applications and impacts on genetic diversity. In: Caliskan M (Ed), Analysis of Genetic Variation in Animals, Rijeka: InTech, 269-286p. https://doi.org/10.5772/2072.

Santos HRS, Gomes UL, Charvet-Almeida P. 2004. A new species of whiptail stingray of the genus Dasyatis Rafinesque, 1810 from the southwestern Atlantic Ocean (Chondrichthyes: Myliobatiformes: Dasyatidae). Zootaxa 492:1-12.

SBEEL (Sociedade Brasileira para o Estudo de Elasmobrânquios). 2005. Plano de Ações para Conservação e Manejo dos Estoques dos Recursos Pesqueiros, 10op. 
Silveira MHF. 2017. Desenvolvimento de métodos moleculares para identificação das principais espécies de raias da região norte do Brasil. Trabalho de Conclusão de Curso apresentado ao curso de Bacharelado em Biologia da Universidade Federal Rural da Amazônia, 47 p.

Studart-Gomes PR. 1988. A pesca industrial de camarão rosa no Norte do Brasil. In: V Congresso Brasileiro de Engenharia de Pesca, 1987. Fortaleza: Associação dos Engenheiros de Pesca do Estado do Ceará, 419-34.

Ussami LHF. 2015. Identificação e estimativa pesqueira de tubarões da costa de São Paulo (Província Argentina) utilizando marcadores genéticos. 2015. $80 \mathrm{f}$. Tese (doutorado em zoologia) - Universidade Estadual Paulista, Botucatu / SP, 2015.

Van der Laan R, Fricke R, Eschmeyer WN (Eds). 2019. Eschmeyer's Catalog of Fishes: classification. Available at http://www.calacademy.org/scientists/catalog-of-fishesclassification/. Accessed on o1 July 2019.

Weigmann S. 2016. Annotated checklist of the living sharks, batoids and chimaeras (Chondrichthyes) of the world, with a focus on biogeographical diversity. Journal of Fish Biology, 88:837-1037. https://doi.org/10.1111/jfb.12874. 
Table 1. List of sharks and batoid species from the Brazilian North coast. A. Species recorded in the present study. B. Species available in the literature on bottom trawling. C. Species recorded in taxonomic works. D. Species recorded in exploratory fishing work. E. Species recorded in molecular identification work. F. Distribution area: (GG) circumglobal; (ED) Pluma do Amazonas-Orinoco endemic; (NE) neotropical; (WA)

Western Atlantic Ocean. G. Habitat: (C) coastal (between o to 100 meters deep); (FW) freshwater (restricted to freshwater influence); (O) oceanic (above 100 meters depth). H. Red List of Threatened Species (IUCN) and Livro Vermelho da Fauna Brasileira Ameaçada de Extinção conservation status (respectively): (CR) critically endangered; (DD) data deficient; (EN) endangered; (LC) least concern; (NT) near threatened; (VU) vulnerable (X) Not Evaluated. I. Type of fishing used for catching: (DT) demersal trawl; (T) traps; (GN) gill net; (L) longline; (X) Not Evaluated.

\begin{tabular}{|c|c|c|c|c|c|c|c|c|c|c|c|c|}
\hline Order & Family & Species & & A & B & $\mathrm{C}$ & $\mathbf{D}$ & $E$ & $\mathbf{F}$ & G & $\mathbf{H}$ & $\mathrm{I}$ \\
\hline Orectolobiformes & Ginglymostomatidae & $\begin{array}{l}\text { Ginglymostoma cirratum } \\
\text { (Bonnaterre 1788) }\end{array}$ & Fig. $2 \mathrm{e}$ & $\mathrm{X}$ & & $\mathrm{X}$ & $\mathrm{X}$ & $\mathrm{X}$ & WA & C & $\mathrm{DD} / \mathrm{VU}$ & DT \\
\hline Laminiformes & Mitsukurinidae & $\begin{array}{l}\text { Mitsukurina owstoni Jordan } \\
1898\end{array}$ & & & & & $\mathrm{X}$ & & CG & $\mathrm{O}$ & LC & $\mathrm{X}$ \\
\hline Laminiformes & Pseudocarchariidae & $\begin{array}{l}\text { Pseudocarcharias kamoharai } \\
\text { (Matsubara 1936) }\end{array}$ & & & & & $\mathrm{X}$ & & CG & $\mathrm{O}$ & $\mathrm{DD} / \mathrm{LC}$ & $\mathrm{L}$ \\
\hline Laminiformes & Alopiidae & $\begin{array}{l}\text { Alopias superciliosus Lowe } \\
1841\end{array}$ & & & & & $\mathrm{X}$ & & CG & $\mathrm{O}$ & VU & $\mathrm{L}$ \\
\hline Laminiformes & Alopiidae & $\begin{array}{l}\text { Alopias vulpinus } \\
\text { (Bonnaterre 1788) }\end{array}$ & & & & & $\mathrm{X}$ & & CG & $\mathrm{O}$ & VU & $\mathrm{L}$ \\
\hline Laminiformes & Laminidae & $\begin{array}{l}\text { Isurus oxyrinchus } \\
\text { Rafinesque } 1810\end{array}$ & & & & & $\mathrm{X}$ & & CG & $\mathrm{O}$ & EN/NT & $\mathrm{L}$ \\
\hline Laminiformes & Laminidae & $\begin{array}{l}\text { Isurus paucus Guitart } \\
\text { Manday } 1966\end{array}$ & & & & & $\mathrm{X}$ & & CG & $\mathrm{O}$ & EN/DD & $\mathrm{L}$ \\
\hline Carcharhiniformes & Scyliorhinidae & $\begin{array}{l}\text { Schroederichthys tenuis } \\
\text { Springer } 1966\end{array}$ & & & & $\mathrm{X}$ & & & ED & $\mathrm{O}$ & DD & DT \\
\hline Carcharhiniformes & Scyliorhinidae & $\begin{array}{l}\text { Scyliorhinus haeckelii } \\
\text { (Miranda Ribeiro 1907) }\end{array}$ & & & & $\mathrm{X}$ & & & WA & C & $\mathrm{DD} / \mathrm{LC}$ & DT \\
\hline Carcharhiniformes & Triakidae & $\begin{array}{l}\text { Mustelus canis (Mitchill } \\
1815 \text { ) }\end{array}$ & Fig. 3a & $\mathrm{X}$ & & $\mathrm{X}$ & $\mathrm{X}$ & & WA & C & NT/EN & DT \\
\hline
\end{tabular}




\begin{tabular}{|c|c|c|c|c|c|c|c|c|c|c|c|c|}
\hline Order & Family & Species & & $\mathbf{A}$ & B & $\mathrm{C}$ & $\mathbf{D}$ & $\mathbf{E}$ & $\mathbf{F}$ & G & $\mathbf{H}$ & $\mathbf{I}$ \\
\hline Carcharhiniformes & Triakidae & $\begin{array}{l}\text { Mustelus higmani Springer } \\
\text { \& Lowe } 1963\end{array}$ & Fig. $3 \mathrm{~b}$ & $\mathrm{X}$ & & $X$ & $\mathrm{X}$ & & WA & C & $\mathrm{LC}$ & DT \\
\hline Carcharhiniformes & Carcharhinidae & $\begin{array}{l}\text { Carcharhinus acronotus } \\
\text { (Poey 1860) }\end{array}$ & Fig. $3 \mathrm{C}$ & $\mathrm{X}$ & & $\mathrm{X}$ & $\mathrm{X}$ & $\mathrm{X}$ & WA & $\mathrm{C}$ & NT & $\begin{array}{l}\text { DT; } \\
\text { GN; L }\end{array}$ \\
\hline Carcharhiniformes & Carcharhinidae & $\begin{array}{l}\text { Carcharhinus brevipinna } \\
\text { (Valenciennes 1839) }\end{array}$ & & & & & $\mathrm{X}$ & & CG & $\mathrm{C}$ & NT/DD & $\mathrm{L}$ \\
\hline Carcharhiniformes & Carcharhinidae & $\begin{array}{l}\text { Carcharhinus falciformis } \\
\text { (Müller \& Henle 1839) }\end{array}$ & Fig. 3d & $\mathrm{X}$ & & $\mathrm{X}$ & $\mathrm{X}$ & & CG & C & $\mathrm{VU} / \mathrm{NT}$ & $\begin{array}{l}\text { DT; } \\
\text { GN; L }\end{array}$ \\
\hline Carcharhiniformes & Carcharhinidae & $\begin{array}{l}\text { Carcharhinus leucas } \\
\text { (Valenciennes 1839) }\end{array}$ & & & & $X$ & & $\mathrm{X}$ & CG & C & NT & GN; L \\
\hline Carcharhiniformes & Carcharhinidae & $\begin{array}{l}\text { Carcharhinus limbatus } \\
\text { (Valenciennes 1839) }\end{array}$ & Fig. $3 \mathrm{e}$ & $\mathrm{X}$ & & $\mathrm{X}$ & $\mathrm{X}$ & $\mathrm{X}$ & CG & C & NT & $\begin{array}{l}\text { DT; } \\
\text { GN; L }\end{array}$ \\
\hline Carcharhiniformes & Carcharhinidae & $\begin{array}{l}\text { Carcharhinus longimanus } \\
\text { (Poey 1861) }\end{array}$ & & & & & $\mathrm{X}$ & & CG & $\mathrm{O}$ & $\mathrm{CR} / \mathrm{VU}$ & $\mathrm{L}$ \\
\hline Carcharhiniformes & Carcharhinidae & $\begin{array}{l}\text { Carcharhinus obscurus } \\
\text { (Lesueur 1818) }\end{array}$ & & & & $X$ & & $\mathrm{X}$ & CG & C & EN & GN \\
\hline Carcharhiniformes & Carcharhinidae & $\begin{array}{l}\text { Carcharhinus perezi (Poey } \\
1876 \text { ) }\end{array}$ & & & & $\mathrm{X}$ & & & WA & C & $\mathrm{NT} / \mathrm{VU}$ & GN; L \\
\hline Carcharhiniformes & Carcharhinidae & $\begin{array}{l}\text { Carcharhinus plumbeus } \\
\text { (Nardo 1827) }\end{array}$ & & & & $\mathrm{X}$ & & & CG & C & $\mathrm{VU} / \mathrm{CR}$ & GN \\
\hline Carcharhiniformes & Carcharhinidae & $\begin{array}{l}\text { Carcharhinus porosus } \\
\text { (Ranzani 1839) }\end{array}$ & & $\mathrm{X}$ & & $\mathrm{X}$ & $\mathrm{X}$ & $\mathrm{X}$ & WA & $\mathrm{C}$ & $\mathrm{DD} / \mathrm{CR}$ & $\begin{array}{l}\text { DT; } \\
\text { GN; L }\end{array}$ \\
\hline Carcharhiniformes & Carcharhinidae & $\begin{array}{l}\text { Galeocerdo cuvier (Péron \& } \\
\text { Lesueur 1822) }\end{array}$ & Fig. $3 \mathrm{f}$ & $\mathrm{X}$ & & $\mathrm{X}$ & $\mathrm{X}$ & $\mathrm{X}$ & CG & C & NT & $\begin{array}{l}\text { DT; } \\
\text { GN; L }\end{array}$ \\
\hline Carcharhiniformes & Carcharhinidae & $\begin{array}{l}\text { Isogomphodon oxyrhynchus } \\
\text { (Müller \& Henle 1839) }\end{array}$ & Fig. 4a & $\mathrm{X}$ & & $\mathrm{X}$ & $\mathrm{X}$ & $\mathrm{X}$ & ED & C & CR & DT; GN \\
\hline Carcharhiniformes & Carcharhinidae & $\begin{array}{l}\text { Negaprion brevirostris (Poey } \\
\text { 1868) }\end{array}$ & & & & $\mathrm{X}$ & & & $\mathrm{NE}$ & C & $\mathrm{NT} / \mathrm{VU}$ & $\mathrm{X}$ \\
\hline Carcharhiniformes & Carcharhinidae & $\begin{array}{l}\text { Prionace glauca (Linnaeus } \\
1758 \text { ) }\end{array}$ & & & & & $\mathrm{X}$ & & CG & $\mathrm{O}$ & NT & $\mathrm{L}$ \\
\hline
\end{tabular}




\begin{tabular}{|c|c|c|c|c|c|c|c|c|c|c|c|c|}
\hline Order & Family & Species & & A & B & $\mathrm{C}$ & $\mathbf{D}$ & $\mathbf{E}$ & $\mathbf{F}$ & G & $\mathbf{H}$ & I \\
\hline Carcharhiniformes & Carcharhinidae & $\begin{array}{l}\text { Rhizoprionodon lalandii } \\
\text { (Valenciennes 1839) }\end{array}$ & Fig. $4 \mathrm{~b}$ & $\mathrm{X}$ & & $\mathrm{X}$ & & $X$ & WA & $\mathrm{C}$ & $\mathrm{DD} / \mathrm{NT}$ & DT; GN \\
\hline Carcharhiniformes & Carcharhinidae & $\begin{array}{l}\text { Rhizoprionodon porosus } \\
\text { (Poey 1861) }\end{array}$ & Fig. 4c & $\mathrm{X}$ & & $\mathrm{X}$ & $\mathrm{X}$ & $\mathrm{X}$ & WA & $\mathrm{C}$ & $\mathrm{LC} / \mathrm{DD}$ & $\begin{array}{l}\text { DT; } \\
\text { GN; L }\end{array}$ \\
\hline Carcharhiniformes & Sphyrnidae & $\begin{array}{l}\text { Sphyrna lewini (Griffith \& } \\
\text { Smith 1834) }\end{array}$ & Fig. 4d & $\mathrm{X}$ & & $\mathrm{X}$ & $\mathrm{X}$ & $\mathrm{X}$ & CG & $\mathrm{C}$ & CR & $\begin{array}{l}\text { DT; } \\
\text { GN; L }\end{array}$ \\
\hline Carcharhiniformes & Sphyrnidae & $\begin{array}{l}\text { Sphyrna media Springer } \\
1940\end{array}$ & & & & $\mathrm{X}$ & & & $\mathrm{NE}$ & $\mathrm{C}$ & $\mathrm{DD} / \mathrm{CR}$ & $\mathrm{X}$ \\
\hline Carcharhiniformes & Sphyrnidae & $\begin{array}{l}\text { Sphyrna mokarran (Rüppell } \\
\text { 1837) }\end{array}$ & Fig. $4 \mathrm{e}$ & $\mathrm{X}$ & & $\mathrm{X}$ & & & CG & C & CR/EN & DT; GN \\
\hline Carcharhiniformes & Sphyrnidae & $\begin{array}{l}\text { Sphyrna tiburo (Linnaeus } \\
\text { 1758) }\end{array}$ & Fig. $4 \mathrm{f}$ & $\mathrm{X}$ & & $\mathrm{X}$ & $\mathrm{X}$ & $\mathrm{X}$ & $\mathrm{NE}$ & $\mathrm{C}$ & $\mathrm{LC} / \mathrm{CR}$ & $\begin{array}{l}\text { DT; } \\
\text { GN; L }\end{array}$ \\
\hline Carcharhiniformes & Sphyrnidae & $\begin{array}{l}\text { Sphyrna tudes } \\
\text { (Valenciennes 1822) }\end{array}$ & & & & $\mathrm{X}$ & & $\mathrm{X}$ & $\mathrm{NE}$ & $\mathrm{C}$ & $\mathrm{VU} / \mathrm{CR}$ & GN \\
\hline Squaliformes & Centrophoridae & $\begin{array}{l}\text { Zameus squamulosus } \\
\text { (Günther 1877) }\end{array}$ & & & & & $\mathrm{X}$ & & CG & $\mathrm{O}$ & $\mathrm{DD} / \mathrm{LC}$ & $\mathrm{X}$ \\
\hline Squatiniformes & Squatinidae & $\begin{array}{l}\text { Squatina dumeril Lesueur } \\
1818\end{array}$ & & & & $\mathrm{X}$ & & & WA & $\mathrm{C}$ & $\mathrm{LC} / \mathrm{DD}$ & $\mathrm{X}$ \\
\hline Torpediniformes & Narcinidae & Diplobatis picta Palmer 1950 & Fig. 5a & $\mathrm{X}$ & & $\mathrm{X}$ & & $\mathrm{X}$ & ED & $\mathrm{C}$ & $\mathrm{VU} / \mathrm{X}$ & DT \\
\hline Torpediniformes & Narcinidae & $\begin{array}{l}\text { Narcine bancroftii (Griffith } \\
\text { \& Smith 1834) }\end{array}$ & Fig. $5 \mathrm{~b}$ & $\mathrm{X}$ & & & & & WA & $\mathrm{C}$ & $\mathrm{LC} / \mathrm{DD}$ & DT; GN \\
\hline Torpediniformes & Narcinidae & $\begin{array}{l}\text { Narcine brasiliensis (Olfers } \\
1831 \text { ) }\end{array}$ & Fig. $5 \mathrm{C}$ & $\mathrm{X}$ & $\mathrm{X}$ & $\mathrm{X}$ & & $\mathrm{X}$ & WA & $\mathrm{C}$ & DD & DT \\
\hline Torpediniformes & Narcinidae & Narcine sp & Fig. $5 \mathrm{~d}$ & $\mathrm{X}$ & & & & & & $\mathrm{C}$ & & DT \\
\hline Rajiformes & Rajidae & $\begin{array}{l}\text { Breviraja spinosa Bigelow \& } \\
\text { Schroeder } 1950\end{array}$ & & & & & $\mathrm{X}$ & & WA & $\mathrm{O}$ & $\mathrm{DD} / \mathrm{LC}$ & $\mathrm{X}$ \\
\hline Rajiformes & Rajidae & $\begin{array}{l}\text { Gurgesiella atlantica } \\
\text { (Bigelow \& Schroeder 1962) }\end{array}$ & & & & $\mathrm{X}$ & & & WA & $\mathrm{O}$ & $\mathrm{DD} / \mathrm{LC}$ & $\mathrm{X}$ \\
\hline Rajiformes & Rajidae & $\begin{array}{l}\text { Rajella purpuriventralis } \\
\text { (Bigelow \& Schroeder 1962) }\end{array}$ & & & & & $\mathrm{X}$ & & WA & $\mathrm{O}$ & LC & $\mathrm{X}$ \\
\hline
\end{tabular}




\begin{tabular}{|c|c|c|c|c|c|c|c|c|c|c|c|c|}
\hline Order & Family & Species & & A & B & $C$ & $\mathbf{D}$ & $\mathbf{E}$ & $\mathbf{F}$ & G & $\mathbf{H}$ & $\mathbf{I}$ \\
\hline Rhinopristiformes & Rhinobatidae & $\begin{array}{l}\text { Pseudobatos horkelii (Müller } \\
\text { \& Henle 1841) }\end{array}$ & Fig. 5e-f & $\mathrm{X}$ & & & & & WA & $\mathrm{C}$ & CR & DT; GN \\
\hline Rhinopristiformes & Rhinobatidae & $\begin{array}{l}\text { Pseudobatos percellens } \\
\text { (Walbaum 1792) }\end{array}$ & Fig. $5 \mathrm{~g}$ & $\mathrm{X}$ & & $\mathrm{X}$ & & & WA & $\mathrm{C}$ & NT/DD & DT \\
\hline Rhinopristiformes & Pristidae & $\begin{array}{l}\text { Pristis pectinata Latham } \\
1794\end{array}$ & & & & $\mathrm{X}$ & & & CG & $\mathrm{C}$ & CR & DT \\
\hline Rhinopristiformes & Pristidae & $\begin{array}{l}\text { Pristis pristis (Linnaeus } \\
1758 \text { ) }\end{array}$ & Fig. 2a & $\mathrm{X}$ & $\mathrm{X}$ & $\mathrm{X}$ & & $\mathrm{X}$ & ED & $C$ & CR & DT \\
\hline Myliobatiformes & Urolophidae & $\begin{array}{l}\text { Urobatis jamaicensis (Cuvier } \\
1816 \text { ) }\end{array}$ & Fig. $5 \mathrm{~h}$ & $\mathrm{X}$ & & & & & WA & $\mathrm{C}$ & LC/X & DT; GN \\
\hline Myliobatiformes & Urolophidae & Urolophus sp & & & & $\mathrm{X}$ & & & & $C$ & & $\mathrm{X}$ \\
\hline Myliobatiformes & Urolophidae & $\begin{array}{l}\text { Urotrygon microphthalmum } \\
\text { Delsman } 1941\end{array}$ & Fig. $5 \mathrm{i}$ & $\mathrm{X}$ & & $\mathrm{X}$ & & & WA & C & $\mathrm{LC} / \mathrm{DD}$ & DT; GN \\
\hline Myliobatiformes & Urolophidae & $\begin{array}{l}\text { Fontitrygon colarensis } \\
\text { (Santos et al 2004) }\end{array}$ & & & & $\mathrm{X}$ & & & ED & $\mathrm{C}$ & VU/VU & $\mathrm{X}$ \\
\hline Myliobatiformes & Dasyatidae & $\begin{array}{l}\text { Fontitrygon geijskesi } \\
\text { (Boeseman 1948) }\end{array}$ & Fig. $2 f$ & $\mathrm{X}$ & $\mathrm{X}$ & & & $\mathrm{X}$ & ED & $\mathrm{C}$ & NT/DD & DT; GN \\
\hline Myliobatiformes & Dasyatidae & $\begin{array}{l}\text { Hypanus americanus } \\
\text { (Hildebrand \& Schroeder } \\
\text { 1928) }\end{array}$ & Fig. $5 j$ & $\mathrm{X}$ & & $\mathrm{X}$ & $\mathrm{X}$ & $\mathrm{X}$ & WA & $\mathrm{C}$ & DD & DT; GN \\
\hline Myliobatiformes & Dasyatidae & $\begin{array}{l}\text { Hypanus guttatus (Bloch \& } \\
\text { Schneider 1801) }\end{array}$ & Fig. $5 \mathrm{k}$ & $\mathrm{X}$ & $\mathrm{X}$ & $\mathrm{X}$ & $\mathrm{X}$ & $\mathrm{X}$ & WA & $C$ & $\mathrm{DD} / \mathrm{LC}$ & DT \\
\hline Myliobatiformes & Dasyatidae & $\begin{array}{l}\text { Hypanus marianae (Gomes } \\
\text { Rosa \& Gadig 2000) }\end{array}$ & & & & & $\mathrm{X}$ & & WA & $\mathrm{C}$ & DD & ES \\
\hline Myliobatiformes & Dasyatidae & $\begin{array}{l}\text { Hypanus sabinus (Lesueur } \\
\text { 1824) }\end{array}$ & & & & & $\mathrm{X}$ & & WA & $C$ & $\mathrm{LC} / \mathrm{X}$ & DT \\
\hline Myliobatiformes & Dasyatidae & Hypanus say (Lesueur 1817) & & & & $\mathrm{X}$ & & & WA & $\mathrm{C}$ & $\mathrm{LC} / \mathrm{DD}$ & $\mathrm{X}$ \\
\hline Myliobatiformes & Potamotrygonidae & $\begin{array}{l}\text { Paratrygon aiereba (Müller } \\
\text { \& Henle 1841) }\end{array}$ & & & & $\mathrm{X}$ & & & ED & FW & $\mathrm{DD} / \mathrm{CR}$ & DT; T \\
\hline
\end{tabular}




\begin{tabular}{|c|c|c|c|c|c|c|c|c|c|c|c|c|}
\hline Order & Family & Species & & A & B & $\mathbf{C}$ & $\mathbf{D}$ & $\mathbf{E}$ & $\mathbf{F}$ & G & $\mathbf{H}$ & I \\
\hline Myliobatiformes & Potamotrygonidae & $\begin{array}{l}\text { Plesiotrygon iwamae Rosa et } \\
\text { al., } 1987\end{array}$ & Fig. 6a & $\mathrm{X}$ & & $\mathrm{X}$ & & & ED & FW & $\mathrm{DD} / \mathrm{NT}$ & DT; T \\
\hline Myliobatiformes & Potamotrygonidae & $\begin{array}{l}\text { Potamotrygon humerosa } \\
\text { Garman, } 1913\end{array}$ & Fig. 6b & $\mathrm{X}$ & & $\mathrm{X}$ & & & $\mathrm{NE}$ & FW & DD & DT; T \\
\hline Myliobatiformes & Potamotrygonidae & $\begin{array}{l}\text { Potamotrygon motoro } \\
\text { (Müller \& Henle 1841) }\end{array}$ & & & & $\mathrm{X}$ & & & $\mathrm{NE}$ & FW & $\mathrm{DD} / \mathrm{LC}$ & DT; T \\
\hline Myliobatiformes & Potamotrygonidae & $\begin{array}{l}\text { Potamotrygon ocellata } \\
\text { (Engelhardt, 1912) }\end{array}$ & & & & $\mathrm{X}$ & & & ED & FW & DD & DT; T \\
\hline Myliobatiformes & Potamotrygonidae & $\begin{array}{l}\text { Potamotrygon orbignyi } \\
\text { (Castelnau 1855) }\end{array}$ & Fig. 6c & $\mathrm{X}$ & & $\mathrm{X}$ & & & $\mathrm{NE}$ & FW & $\mathrm{LC}$ & DT \\
\hline Myliobatiformes & Potamotrygonidae & $\begin{array}{l}\text { Potamotrygon scobina } \\
\text { (Müller \& Henle 1841) }\end{array}$ & & & $\mathrm{X}$ & $\mathrm{X}$ & & & ED & FW & $\mathrm{DD} / \mathrm{LC}$ & DT \\
\hline Myliobatiformes & Potamotrygonidae & $\begin{array}{l}\text { Styracura schmardae } \\
\text { (Werner 1904) }\end{array}$ & Fig. 6d & $\mathrm{X}$ & & $\mathrm{X}$ & & & ED & $\mathrm{C}$ & DD & DT; GN \\
\hline Myliobatiformes & Gymnuridae & $\begin{array}{l}\text { Gymnura micrura (Bloch \& } \\
\text { Schneider 1801) }\end{array}$ & Fig. 6e-f & $\mathrm{X}$ & $\mathrm{X}$ & $\mathrm{X}$ & $\mathrm{X}$ & $\mathrm{X}$ & WA & $\mathrm{C}$ & $\mathrm{DD} / \mathrm{NT}$ & DT; GN \\
\hline Myliobatiformes & Myliobatidae & $\begin{array}{l}\text { Aetobatus narinari } \\
\text { (Euphrasen 1790) }\end{array}$ & Fig. 6g & $\mathrm{X}$ & $\mathrm{X}$ & $\mathrm{X}$ & & $\mathrm{X}$ & WA & C & NT/DD & DT; GN \\
\hline Myliobatiformes & Myliobatidae & $\begin{array}{l}\text { Mobula birostris (Walbaum } \\
1792 \text { ) }\end{array}$ & & & $\mathrm{X}$ & & & & CG & $\mathrm{C}$ & VU & $\mathrm{X}$ \\
\hline Myliobatiformes & Myliobatidae & $\begin{array}{l}\text { Mobula hypostoma } \\
\text { (Bancroft 1831) }\end{array}$ & & & & $\mathrm{X}$ & & & WA & $\mathrm{C}$ & EN/VU & GN \\
\hline Myliobatiformes & Myliobatidae & $\begin{array}{l}\text { Rhinoptera brasiliensis } \\
\text { Müller } 1836\end{array}$ & Fig. 6h & $\mathrm{X}$ & & & & $\mathrm{X}$ & WA & $\mathrm{C}$ & EN/CR & DT; GN \\
\hline Myliobatiformes & Myliobatidae & $\begin{array}{l}\text { Rhinoptera bonasus } \\
\text { (Mitchill 1815) }\end{array}$ & Fig. $6 \mathrm{i}$ & $\mathrm{X}$ & $\mathrm{X}$ & $\mathrm{X}$ & & $\mathrm{X}$ & WA & $\mathrm{C}$ & NT/DD & DT \\
\hline
\end{tabular}

